\title{
PENGARUH HEALTH EDUCATION TERHADAP PERILAKU VULVA HYGIENE SAAT MENSTRUASI ANAK SD UMUR 11 - 13 TAHUN DI SDN MOJOSARI KABUPATEN MOJOKERTO
}

\author{
Siti Muthoharoh $^{1}$, Rina Widiyawati ${ }^{1}$ \\ ${ }^{1}$ STIKES Dian Husada Mojokerto \\ *Correspondence: \\ Siti Muthoharoh \\ Email: sitimuthoharoh313@gmail.com
}

\begin{abstract}
Background: Perawatan vulva hygiene saat menstruasi seharusnya mengganti pembalut secara teratur yaitu sebanyak 3-4 kali sehari. Kenyataannya anak mempunyai perilaku yang buruk pada hygiene saat menstruasi seperti tidak sering mengganti celana dalam dan pembalut sehingga akan menimbulkan mikroorganisme seperti bakteri, jamur, virus yang berlebihan dan dapat mengganggu organ reproduksi.

Purpose: Penelitian ini bertujuan untuk mengetahui pengaruh health education terhadap perilaku vulva hygiene saat menstruasi anak SD umur 11 - 13 tahun di SDN Mojosari.

Method: Desain penelitian yang digunakan dalam penelitian ini adalah Pra Eksperimental dengan metode One group Pretest-Postest Desain. Populasi dalam penelitian ini adalah anak perempuan berumur 11 - 13 tahun yang sudah menstruasi di SDN Mojosari, menggunakan metode Non-Probability Sampling. Sampel sebanyak 16 siswi. Setelah data terkumpul, maka dilakukan pengolahan data melalui tahapan editing, coding, scoring dan tabulating. analisis data menggunakan Uji t-test untuk menguji hipotesis komparatif bila datanya berbentuk nominal.

Results: Hasil penelitian menunjukkan bahwa sebagian kecil perilaku vulva hygiene anak berumur 11 - 13 tahun saat menstruasi responden adalah positif sebanyak 4 orang $(25,0 \%)$. Diatas setengah perilaku vulva hygiene anak berumur $11-13$ tahun saat menstruasi responden adalah positif sebanyak 11 orang $(68,8 \%)$. Ada pengaruh health education terhadap perilaku vulva hygiene anak berumur $11-$ 13 tahun saat menstruasi di SDN Mojosari dengan hasil uji t-test nilai sig. $0,016<\alpha 0,05$.

Conclusion: Berdasarkan hasil penelitian ini diharapkan siswi untuk selalu menjaga daerah kewanitaan dengan melakukan vulva hyiene dengan tepat dan benar sesuai dengan ketentuan dari tenaga kesehatan terutama pada saat menstruasi.
\end{abstract}

Key words: Health Education, Vulva Hygiene, Perilaku

\section{PENDAHULUAN}

Personal hygiene saat menstruasi adalah tindakan untuk memelihara kesehatan dan kebersihan pada daerah kewanitaan pada saat menstruasi (Laksamana, 2001). Menurut teori perawatan vulva hygiene saat menstruasi seharusnya mengganti pembalut secara teratur yaitu sebanyak 3-4 kali sehari. Kenyataannya anak mempunyai perilaku yang buruk pada hygiene saat menstruasi seperti tidak sering mengganti celana dalam dan pembalut sehingga akan menimbulkan mikroorganisme seperti bakteri, jamur, 
virus yang berlebihan dan dapat mengganggu organ reproduksi (Indriastuti, 2009). Berdasarkan studi pendahuluan di SDN Mojosari Kabupaten Mojokerto melalui wawancara dengan anak berumur 11 - 13 tahun, ditemukan ada yang mengalami gatal-gatal di daerah sekitar kemaluan setiap menstruasi, dan mereka mengatakan mengganti pembalut jika volume pembalut sudah penuh.

Menurut data Badan Pusat Statistik (BPS) dan Bappenas tahun 2010 dikutip dalam Aisyaroh (2010), sebagian besar dari 63 juta jiwa anak di Indonesia rentan berperilaku tidak sehat seperti kurang menjaga kebersihan, contohnya mengganti pembalut tidak teratur. Perilaku buruk dalam menjaga hygiene pada saat menstruasi dapat menjadi pencetus timbulnya Infeksi Saluran Reproduksi (ISR) (Ratna, 2010). Doxanakis (2004) menemukan dari sampel 303 wanita di Amerika Serikat, sekitar 7\% melaporkan riwayat gatal vagina yang persisten atau adanya sensasi terbakar pada vagina yang berlangsung lebih dari 3 bulan. Jumlah kasus ISR (Infeksi Saluran Reproduksi) di Jawa Timur seperti candidiasis dan servisitis yang terjadi pada anak perempuan sebanyak 86,5\% dari $100 \%$ ditemukan di Surabaya dan Malang. Penyebab tertinggi dari kasus tersebut adalah jamur candida albican sebanyak $77 \%$. Status atau keadaan kesehatan mereka saat iniakan sangat menentukan kesehatan mereka di saat dewasa. Upaya untuk menuju reproduksi sehat dimana remaja harus dipersiapkan baik pengetahuan, sikap dan perilakunya kearah pencapaian reproduksi yang sehat (WHO,2005). Dari data WHO, 2005 terdapat 4 pertanyaan tentang pengertian menstruasi, pengertian siklus menstruasi, siklus menstruasi yang normal dan cara membersihkan vagina yang tepat saat menstruasi yang menjawab benar semua pertanyaan hanya $17,4 \%$ dari $100 \%$ yang ditanya (Ariyani, 2009). Hasil studi pendahuluan di wilayah kerja puskesmas Pungging melalui wawancara dengan siswi mengenai perilaku vulva hygiene saat menstruasi ditemukan anak umur $11-13$ tahun yang berperilaku kurang tepat seperti mengganti pembalut jika volume pembalut sudah penuh, membersihkan organ reproduksi menggunakan sabun mandi atau memakai pembersih daerah kewanitaan secara berlebihan dan tidak menjaga kebersihan celana dalam saat menstruasi.

Perilaku hygiene pada saat menstruasi tidak terjadi begitu saja, tetapi merupakan sebuah proses yang dipelajari (Indriastuti, 2009). Perilaku seseorang dipengaruhi oleh tingkat pendidikan dan pengetahuannya. Pengetahuan seseorang tentang sesuatu dapat menyebabkan perubahan perilaku (Notoadmodjo, 2003). Tingkat pengetahuan yang kurang dikarenakan beberapa hal, yaitu penyampaian informasi yang kurang tepat atau kurang lengkap dan sumber informasi yang salah (Sarwono, 2006). Kurangnya pengetahuan para siswi membuat mereka melakukan vulva hygiene dengan cara yang kurang tepat. Kebersihan selama menstruasi ini sangat penting, karena bila penanganan selama haid tidak benar maka dapat mengakibatkan infeksi alat reproduksi. Infeksi pada alat reproduksi ini mempunyai dampak yang buruk ke masa depan, seperti kemandulan yang mengakibatkan menurunnya kualitas hidup individu yang bersangkutan (Depkes, 1996 dalam Aryani, 2009).

Peran profesi keperawatan dalam hal ini yaitu lebih intensif dalam memberikan pendidikan kesehatan yang 
tepat untuk memberikan pengetahuan tentang bagaimana cara melakukan vulva hygiene yang tepat supaya anak tidak lagi meremehkan pentingnya melakukan vulva hygiene dan lebih waspada akan dampak yang terjadi jika melalaikan vulva hygiene tersebut. Program health education dapat dijadikan sebagai acuan dalam proses belajar, yang dapat dijadikan sebagai faktor yang mempengaruhi proses perubahan perilaku tersebut dan berperilaku baru sesuai dengan pengetahuan yang telah didapat. Dengan memberikan health education tentang vulva hygiene diharapkan dapat meningkatkan perilaku hygiene saat menstruasi pada anak perempuan kearah yang lebih baik sehingga dapat menjaga organ reproduksinya dengan baik.

\section{METODE DAN BAHAN}

Desain penelitian yang digunakan dalam penelitian ini adalah Pra Eksperimental dengan metode One group Pretest-Postest Desain dimana sebelum dan sesudah dilakukan health education dengan metode penyuluhan peneliti membagikan lembar kuesioner kepada responden dan ciri dari rancangan ini adalah tidak ada kelompok pembanding (kontrol).

Peneliti menggunakan desain tersebut karena peneliti ingin menguji dan mengetahui pengaruh health education terhadap perilaku vulva hygiene saat menstruasi anak umur $11-13$ tahun di SDN Mojosari Kabupaten Mojokerto. Populasi dalam penelitian ini adalah siswi SD kelas V dan VI yang berusia $11-13$ tahun sudah menstruasi di SDN Mojosari Kabupaten Mojokerto pada bulan Maret. Sampel penelitian ini adalah diambil dari seluruh siswi kelas V dan VI yang sudah menstruasi di SDN Mojosari, Kabupaten Mojokerto sebanyak 16 siswi. Variabel independen dalam penelitian ini adalah health education. Dan variabel dependen penelitian ini adalah perilaku vulva hygiene saat menstruasi.

Studi pendahuluan dimulai dengan pengambilan data awal populasi yaitu dengan cara mengisi kuesioner data umum yang telah disediakan peneliti yang berisi nama, usia, pendidikan orang tua, pekerjaan orang tua, dan sumber informasi tentang kebersihan organ kewanitaan dan menstruasi. Untuk pengukuran Pre-Test, responden mengisi kuesioner perilaku vulva hygiene saat menstruasi untuk mengetahui perilaku responden sebelum mendapat pendidikan kesehatan dari peneliti dengan metode ceramah dan demonstrasi. Sedangkan untuk pengukuran Post-Test, responden mengisi kuesioner perilaku vulva hygiene saat menstruasi pada saat siswi sudah mengalami menstruasi untuk mengetahui perilaku responden sesudah mendapat pendidikan kesehatan dari peneliti.

Instrumen yang digunakan untuk pengumpulan data pada penelitian ini dengan menggunakan lembar kuesioner perilaku yang terdiri dari 20 pertanyaan. Untuk health education, peneliti menggunakan instrumen SAP vulva hygiene dengan metode penyuluhan yang ditampilkan menggunakan media leafleat dan LCD. 
HASIL PENELITIAN

Karakteristik Responden Berdasarkan Usia.

Tabel 1. Karakteristik Responden Berdasarkan Usia Siswi SD Kelas V dan VI yang berusia 11 - 13 Tahun Sudah Menstruasi di SDN Mojosari Kabupaten Mojokerto pada Bulan Maret.

\begin{tabular}{|c|l|c|c|}
\hline No & Umur (Tahun) & Frekuensi & Prosentase (\%) \\
\hline 1 & 10 & 4 & 25,0 \\
2 & 11 & 3 & 18,8 \\
3 & 12 & 9 & 56,3 \\
\hline \multicolumn{2}{|c|}{ Jumlah } & 16 & 100 \\
\hline
\end{tabular}

Berdasarkan tabel 1 dapat menunjukkan bahwa setengah responden $(56,3 \%)$ berusia 12 tahun sebanyak 9 orang.

Karakteristik Responden Berdasarkan Kelas.

Tabel 2. Karakteristik Responden Berdasarkan Kelas siswi SD yang Berusia 11 - 13 Tahun Sudah Menstruasi di SDN Mojosari Kabupaten Mojokerto pada Bulan Maret.

\begin{tabular}{|c|c|c|c|}
\hline No & Kelas & Frekuensi & Prosentase (\%) \\
\hline 1 & V & 6 & 37,5 \\
2 & VI & 10 & 62,5 \\
\hline \multicolumn{2}{|c|}{ Jumlah } & 16 & 100 \\
\hline
\end{tabular}

Berdasarkan hasil penelitian diatas dapat diketahui bahwa setengah responden $(62,5 \%)$ kelas VI sebanyak 10 orang.

\section{Karakteristik Responden Berdasarkan Pendidikan Orangtua.}

Tabel 3. Karakteristik Responden Berdasarkan Pendidikan Orangtua siswi SD yang berusia 11 - 13 Tahun Sudah Menstruasi di SDN Mojosari Kabupaten Mojokerto pada Bulan Maret.

\begin{tabular}{|c|l|c|c|}
\hline No & Pendidikan Orangtua & Frekuensi & Prosentase (\%) \\
\hline 1 & Tidak sekolah & 4 & 25,0 \\
2 & SD & 6 & 37,5 \\
3 & SMP & 3 & 18,8 \\
4 & SMA & 2 & 12,5 \\
5 & Pendidikan tinggi & 1 & 6,3 \\
\hline \multicolumn{2}{|c|}{ Jumlah } & 16 & 100 \\
\hline
\end{tabular}

Berdasarkan tabel 3 dapat menunjukkan bahwa hampir setengahnya orang tua responden $(37,5 \%)$ tamatan SD sebanyak 6 orang.

\section{Karakteristik Responden Berdasarkan Sumber Informasi.}

Tabel 4. Karakteristik Responden Berdasarkan Sumber Informasi yang Diterima Oleh Siswi SD Kelas V dan VI yang berusia 11 - 13 Tahun Sudah Menstruasi di SDN Mojosari Kabupaten Mojokerto pada Bulan Maret.

\begin{tabular}{|c|l|c|c|}
\hline No & Sumber Informasi & Frekuensi & Prosentase (\%) \\
\hline 1 & Keluarga & 2 & 12,5 \\
2 & Iklan di TV & 9 & 56,3 \\
3 & Tenaga Kesehatan & 2 & 12,5 \\
4 & Majalah & 2 & 12,5 \\
5 & Teman & 1 & 6,3 \\
\hline \multicolumn{2}{|c|}{ Jumlah } & 16 & 100 \\
\hline
\end{tabular}

Dari tabel 4 diketahui bahwa setengah responden $(56,3 \%)$ mendapatkan informasi kesehatan dari iklan TV sebanyak 9 orang. 
Karakteristik Responden Berdasarkan

Perilaku Vulva Hygiene Saat Menstruasu Sebelum Diberi Pendidikan Kesehatan.

Tabel 5. Karakteristik Responden Berdasarkan Perilaku Vulva Hygiene Saat Menstruasi Sebelum Diberi Pendidikan Kesehatan pada Siswi SD Kelas V dan VI yang berusia 11 - 13 Tahun Sudah Menstruasi di SDN Mojosari Kabupaten Mojokerto pada Bulan Maret.

\begin{tabular}{|c|l|c|c|}
\hline No & $\begin{array}{c}\text { Perilaku sebelum } \\
\text { diberi HE }\end{array}$ & Frekuensi & Prosentase (\%) \\
\hline 1 & Positif & 4 & 25,0 \\
2 & Negatif & 12 & 75,0 \\
\hline \multicolumn{2}{|c|}{ Jumlah } & 16 & 100 \\
\hline
\end{tabular}

Berdasarkan data pada tabel 5 diketahui bahwa sebagian besar perilaku vulva hygiene saat menstruasi yang dilakukan oleh responden adalah negatif sebanyak 12 orang $(75,0 \%)$, dan sebagian kecil responden adalah positif sebanyak 4 orang $(25,0 \%)$.

Karakteristik Responden Berdasarkan Perilaku Vulva Hygiene Saat Menstruasu Setelah Diberi Pendidikan Kesehatan.

Tabel 6. Karakteristik Responden Berdasarkan Perilaku Vulva Hygiene Saat Menstruasi Setelah Diberi Pendidikan Kesehatan pada Siswi SD Kelas V dan VI yang berusia 11 - 13 Tahun Sudah Menstruasi di SDN Mojosari Kabupaten Mojokerto pada Bulan Maret.

\begin{tabular}{|c|l|c|c|}
\hline No & $\begin{array}{c}\text { Perilaku setelah } \\
\text { diberi HE }\end{array}$ & Frekuensi & Prosentase (\%) \\
\hline 1 & Positif & 11 & 68,8 \\
2 & Negatif & 5 & 31,3 \\
\hline \multicolumn{2}{|c|}{ Jumlah } & 16 & 100 \\
\hline
\end{tabular}

Berdasarkan hasil data pada tabel 6 didapatkan bahwa sebagian besar perilaku vulva hygiene saat menstruasi yang dilakukan responden adalah positif sebanyak 11 orang $(68,8 \%)$.

\section{Pengaruh Pendidikan Kesehatan Terhadap Perilaku Vulva Hygiene Saat Mentruasi.}

Tabel 7. Hasil Analisa Statistik Terhadap Perilaku Vulva Hygiene saat Mentruasi pada Siswi SD Kelas V dan VI yang berusia 11 - 13 Tahun Sudah Menstruasi di SDN Mojosari Kabupaten Mojokerto pada Bulan Maret.

\begin{tabular}{cccccc}
\hline No & $\begin{array}{c}\text { Perilaku Vulva } \\
\text { Hygiene Saat } \\
\end{array}$ & Menstruasi & Sebelum & \multicolumn{2}{c}{ Setelah } \\
\cline { 3 - 6 } & Positif & 4 & f & $\%$ \\
\hline 1 & Negatif & 12 & 75,0 & 5 & 31,3 \\
\hline & Jumlah & 16 & 100 & 16 & 100 \\
\hline & Hasil uji t-test nilai sig. $0,016<\alpha$ & 0,05 & \\
\hline
\end{tabular}

Berdasarkan hasil penelitian menunjukkan bahwa diatas sebagian besar perilaku vulva hygiene saat menstruasi yang dilakukan responden sebelum diberi pendidikan kesehatan adalah negatif sebanyak 12 orang $(75,0 \%)$, sedangkan setelah diberi pendidikan kesehatan menunjukkan bahwa sebagian besar perilaku vulva hygiene yang dilakukan responden adalah positif sebanyak 11 orang $(68,8 \%)$. berdasarkan penelitian tersebut dapat disimpulkan adanya perubahan perilaku pada kelompok sebelum dan setelah, yaitu perilaku negatif menjadi positif.

Analisa dengan menggunakan uji ttest nilai sig. $0,016<\alpha 0,05$ artinya $\mathrm{H} 1$ diterima ada pengaruh pendidikan kesehatan terhadap perilaku vulva hygiene saat menstruasi di SDN Mojosari Kabupaten Mojokerto. 
PEMBAHASAN

\section{Perilaku Vulva Hygiene Saat Menstruasi Sebelum Diberi Pendidikan Kesehatan}

Berdasarkan

penelitian

menunjukkan bahwa diatas setengah perilaku vulva hygiene saat menstruasi responden adalah negatif sebanyak 12 orang $(75,0 \%)$.

Perilaku hygiene pada saat menstruasi tidak terjadi begitu saja, tetapi merupakan sebuah proses yang dipelajari (Indriastuti, 2009). Perilaku seseorang dipengaruhi oleh tingkat pendidikan dan pengetahuannya. Pengetahuan seseorang tentang sesuatu dapat menyebabkan perubahan perilaku (Notoadmodjo, 2003). Tingkat pengetahuan yang kurang dikarenakan beberapa hal, yaitu penyampaian informasi yang kurang tepat atau kurang lengkap dan sumber informasi yang salah (Sarwono, 2006).

Perilaku negatif responden terkait dengan vulva hygiene saat menstruasi terlihat pada hasil kuesioner yang diajukan oleh peneliti, mereka rata-rata tidak tahu bagaimana cara melakukan vulva hygiene saat menstruasi termasuk mengganti pembalut dan membersihkan daerah kewanitaan saat menstruasi, hal ini karena mereka merupakan anak SD dan merasa tabu jika bertanya tentang daerah kewanitaan, sehingga mereka lebih nyaman bertanya teman maupun melihat atau mendapatkan informasi melalui media televisi. Informasi melalui teman atau media TV merupakan sumber informasi yang kurang bisa dipertanggungjawabkan. Atau hanya sekedar informasi sambil lalu, hal ini diketahui melalui hasil jawaban responden terkait dengan karakteristiknya. Sebagian besar responden mendapatkan informasi kesehatan terutama tentang vulva hygiene adalah melalui media TV dan sebagian kecil dari teman, sementara pertilaku negatif juga terdapat pada responden yang orang tuanya hanya berpendidikan SD, karena selama ini mereka juga mendapatkan informasi tentang kesehatan dari orang tua sementara pendidikan orang tua adalah tingkat SD sehingga apa yang disampaikan oleh orang tua kurang mengena yang mengakibatkan perilaku responden sebagian besar adalah negatif. Perilaku negatif dapat disebabkan oleh faktor umur, pendidikan orang tua dan sumber informasi.

Berdasarkan penelitian yang sudah dilakukan menunjukkan bahwa diatas setengah responden berusia 12 tahun sebanyak 9 orang (56,3\%). Dengan bertambahnya umur seseorang akan terjadi perubahan dan pada aspek fisik dan psikologis (mental). Pertumbuhan pada fisik secara garis besar ada empat kategori perubahan pertama, perubahan ukuran, kedua, perubahan proporsi, ketiga, hilangnya ciri-ciri lama, keempat, timbulnya ciri-ciri baru. Ini terjadi akibat pematangan fungsi organ. Pada aspek psikologis atau mental taraf berpikir semakin matang dan dewasa (Mubarok, 2007).

Usia responden termasuk dalam kategori usia pra pubertas dimana responden masih dalam masa belajar sehingga rentang usia responden masih relatif sama, hal ini ditunjukan bahwa responden dengan usia 12 tahun sebagian besar perilaku vulva hygiene-nya adalah negatif sebanyak 7 responden. Sedangkan responden yang berusia 10 tahun juga negatif dan bahkan responden yang berusia 11 tahun juga relatif negatif. Hal ini mengindikasikan bahwa faktor usia tidak begitu berpengaruh terhadap perilaku responden terkait dengan vulva hygiene. 
Berdasarkan penelitian yang sudah dilakukan menunjukkan bahwa hampir setengahnya orang tua responden tamatan SD sebanyak 6 orang (37,5\%). Pendidikan merupakan salah faktor yang mempengaruhi tingkat pengetahuan seseorang. Latar belakang pendidikan terakhir seseorang dapat mempengaruhi tingkat pengetahuan karena pendidikan akan mempengaruhi proses belajar seseorang. Semakin tinggi pendidikan maka akan semakin mudah seseorang tersebut dalam menerima sebuah informasi. Semakin banyak informasi yang diterima, maka semakin banyak pula pengetahuan yang didapat. Namun perlu ditekankan bahwa seseorang yang berpendidikan rendah tidak berarti mutlak berpengetahuan rendah (Notoatmodjo, 2010).

Orang tua responden sebagian besar hanya lulusan SD meskipun demikian terdapat responden yang orang tuanya tidak sekolah mempunyai perilaku negatif, hal ini menunjukkan bahwa pendidikan orang tua juga tidak berpengaruh terhadap perilaku responden terkait dengan perilaku vulva hygiene.

Berdasarkan penelitian yang sudah dilakukan menunjukkan bahwa diatas setengah responden mendapatkan informasi kesehatan dari iklan TV sebanyak 9 orang $(56,3 \%)$. Sumber informasi berkaitan dengan baik dan tidaknya pengetahuan yang diperoleh, tepatnya sumber informasi yang didapat akan menambah wawasan dan pengetahuan seseorang (Notoatmodjo, 2010).

Sebagian besar responden mendapatkan informasi tentang vulva hygiene dari iklan TV, sumber informasi yang bersumber dari iklan tv merupakan informasi yang kurang tepat karena informasi yang disampaikan melalui iklan hanya bersifat sementara, sehingga kurang berpengaruh terhadap perilaku responden.

\section{Perilaku Vulva Hygiene Saat Menstruasi Setelah Diberi Health Education}

Berdasarkan penelitian yang sudah dilakukan menunjukkan bahwa diatas setengah perilaku vulva hygiene saat menstruasi responden adalah positif sebanyak 11 orang $(68,8 \%)$.

Health education adalah suatu proses perubahan pada diri manusia yang ada hubungannya dengan tercapainya tujuan kesehatan perorangan dan masyarakat juga dapat diartikan sejumlah pengalaman yang berpengaruh secara menguntungkan terhadap kebiasaan, sikap, pengetahuan yang ada hubungannya dengan kesehatan perorangan, masyarakat dan bangsa (Machfoedz (2005). Pendidikan kesehatan di sekolah, dilakukan di sekolah dengan sasaran murid. Menurut Mubarak et al. (2007), Sasaran pendidikan kesehatan dibagi dalam tiga kelompok sasaran, yaitu: Sasaran primer (Primary Target), sasaran langsung pada masyarakat, mencakup segala upaya pendidikan/ promosi kesehatanperilaku dipengaruhi oleh 3 faktor utama, yakni: Faktor predisposisi (predisposing faktor). Merupakan faktor internal yang ada pada diri individu, keluarga, kelompok, atau masyarakat yang mempermudah individu untuk berperilaku yang terwujud dalam pengetahuan, sikap, kepercayaan, keyakinan, nilai-nilai dan sebagainya. Faktor pendukung (enabling factor). Faktor-faktor ini mencakup ketersediaan sarana dan prasarana atau fasilitas kesehatan bagi masyarakat. Faktor pendorong (reinforcing factor) merupakan faktor yang menguatkan perilaku, yang terwujud dalam sikap dan perilaku petugas kesehatan, teman sebaya, orang tua, yang 
merupakan kelompok referensi dan perilaku masyarakat. Perilaku manusia sebagian besar ialah berupa perilaku yang dibentuk dan perilaku yang di pelajari (Nursalam, 2013).

Perilaku responden setelah diberi pendidikan kesehatan tentang vulva hygiene menjadi positif, responden telah mendapatkan pendidikan kesehatan yang tepat, karena dengan diberikanya pendidikan kesehatan responden menjadi lebih tahu terkait dengan vulva hygiene. Perilaku positif yang terdapat pada responden dipengaruhi oleh tambahnya pengetahuan responden karena adanya pendidikan kesehatan yang diterimanya. Ada 5 responden $(31,3 \%)$ yang perilakunya masih negatif dikarenakan daya pikir masing-masing anak berbeda. Hal ini diketahui melalui hasil kuesioner bahwa responden menjadi bisa menjawab seluruh pertanyaan yang diberikan oleh peneliti terkait dengan vulva hygiene. Dengan demikian faktor yang lebih dominan berpengaruh terhadap perilaku responden adalah faktor pengetahuan yang diperoleh melalui pendidikan kesehatan. Hal ini menunjukkan bahwa pendidikan kesehatan sangat dibutuhkan oleh masyarakat karena mampu merubah perilaku kesehatan.

\section{Pengaruh perilaku vulva hygiene saat menstruasi sebelum dan setelah diberi pendidikan kesehatan}

Concrete Operasional (7-11 tahun) yaitu anak sudah memandang realistis dari dunianya dan mempunyai anggapan yang sama dengan orang lain, sifat egosentrik sudah hilang, karena anak sudah mengerti tentang keterbatasan diri sendiri.

Berdasarkan penelitian yang sudah dilakukan menunjukkan bahwa diatas sebagian besar perilaku vulva hygiene saat menstruasi yang dilakukan responden adalah negatif sebanyak 12 orang $(75,0 \%)$, dan positif pada sebagian kecil responden sebanyak 4 orang $(25,0 \%)$, sedangkan setelah diberi pendididikan kesehatan menunjukkan bahwa sebagian besar responden memiliki perilaku positif sebanyak 11 orang $(68,8 \%)$ dan masih ada responden yang berperilaku negatif sebanyak 5 responden $(31,3 \%)$. Hasil uji ttest nilai sig. $0,016<\alpha 0,05$, artinya $\mathrm{H} 1$ diterima, dimana hal tersebut menjelaskan bahwa ada pengaruh pendidikan kesehatan terhadap perilaku vulva hygiene saat menstruasi di SDN Mojosari Kabupaten Mojokerto.

Perilaku hygiene pada saat menstruasi tidak terjadi begitu saja, tetapi merupakan sebuah proses yang dipelajari (Indriastuti, 2009). Perilaku seseorang dipengaruhi oleh tingkat pendidikan dan pengetahuannya. Pengetahuan seseorang tentang sesuatu dapat menyebabkan perubahan perilaku (Notoadmodjo, 2003). Tingkat pengetahuan yang kurang dikarenakan beberapa hal, yaitu penyampaian informasi yang kurang tepat atau kurang lengkap dan sumber informasi yang salah (Sarwono, 2006). Kurangnya pengetahuan para siswi membuat mereka melakukan vulva hygiene dengan cara yang kurang tepat. Kebersihan selama menstruasi ini sangat penting, karena bila penanganan selama haid tidak benar maka dapat mengakibatkan infeksi alat reproduksi. Infeksi pada alat reproduksi ini mempunyai dampak yang buruk ke masa depan, seperti kemandulan yang mengakibatkan menurunnya kualitas hidup individu yang bersangkutan (Depkes, 1996 dalam Aryani, 2009).

Responden sebelum diberi pendidikan kesehatan perilaku vulva 
hygiene-nya adalah negatif yaitu responden tidak tahu bagaimana cara melakukan vulva hygiene yang tepat saat mengalami mesntruasi. Yaitu membersihkan daerah kewanitaan dengan sabun mandi dan menggunakan pembersih kewanitaan secara berlebihan. Namun setelah diberi pendidikan kesehatan perilaku mereka menjadi positif, yaitu mencuci tangan menggunakan sabun setelah buang air kecil untuk menambah kebersihan dari kuman, mencuci tangan menggunakan sabun setelah buang air besar dapat menambah kebersihan dari kuman, membasuh daerah kewanitaan dari arah depan ke belakang. Hal ini menunjukkan bahwa pendidikan kesehatan mampu menambah pengetahuan, dengan adanya pengetahuan cukup tentang vulva hygiene maka perilaku hygiene akan terbentuk pula, oleh karena itu pendidikan kesehatan sangat menentukan pengetahuan responden sebagai upaya untuk membentuk perilakunya.

\section{SIMPULAN}

1. Sebelum diberi pendidikan kesehatan tentang perilaku vulva hygiene didapatkan bahwa sebagian kecil responden memiliki perilaku positif terhadap vulva hygiene sebanyak 4 orang $(25,0 \%)$.

2. Setelah diberi pendidikan kesehatan tentang perilaku vulva hygiene didapatkan bahwa sebagian besar responden memiliki perilaku positif terhadap vulva hygiene sebanyak 11 orang $(68,8 \%)$.

3. Ada pengaruh pendidikan kesehatan terhadap perilaku vulva hygiene siswi SD saat menstruasi di SDN Mojosari Kabupaten Mojokerto yang ditunjukkan dengan hasil uji t-test nilai sig. $0,016<\alpha 0,05$.

\section{SARAN}

Tenaga kesehatan sebagai salah satu tenaga yang terdidik yang memiliki tugas untuk memberikan health education diharapkan dapat lebih aktif untuk melakukan kegiatan penyuluhan terkait vulva higiene di masyarakat, terutama pada umur 11 - 13 tahun untuk menghindari masalah reproduksi akibat kurangnya menjaga personal hygiene.

\section{DAFTAR PUSTAKA}

1. Aisyaroh, N. (2010). Kesehatan Reproduksi Remaja. Jurnal Majalah Ilmiah Sultan Agung. Universitas Sultan Agung.

2. Andira, D. (2010). Seluk Beluk Kesehatan Reproduksi Wanita. Yogyakarta: A+ Plus Books.

3. Ariyani, I. (2009). Aspek Biopsikososial Hygiene Menstruasi Siswi Pondok Pesantren.

4. Azwar, S. (2008). Sikap Manusia Teori dan Pengukurannya. Yogyakarta: Pustaka Pelajar.

5. Doxanakis, A., Bradshaw, C., Fairley, C. And Pokorny, C.S. (2004) vulva itch :all that itches is not trush. Medicine Today. 54-63.

6. Dwikarya, M. (2005). Menjaga Organ Intim, Penyakit dan Penanggulangannya. Jakarta: Kawan Pustaka.

7. Indah, F. T. N. (2012). Kejadian Pruritus Vulvae saat Menstruasi pada Remaja Putri.

8. Indriastuti, Putri. (2009). Hubungan antara Pengetahuan Kesehatan Reproduksi dengan Perilaku Hygienis Remaja Putri pada saat Menstruasi. Thesis, Universitas Muhammadiyah Surakarta. 3-8.

9. Kusmiran, E. (2012). Kesehatan Reproduksi Remaja dan Wanita. Jakarta: Salemba Medika.

10. Laksamana. (2001). Kebutuhan Dasar Manusia. Jakarta: Gramedia Pustaka. 
11. Machfoedz, I. et all. (2005). Pendidikan Kesehatan bagian dari Promosi Kesehatan.Yogyakarta: Fitramaya.

12. Manuaba, I (2002). Memahami Kesehatan Reproduksi Wanita. Jakarta: EGC.

13. Maulana, H. (2009). Promosi Kesehatan. Jakarta: EGC.

14. Mubarak, W. et all. (2007). Promosi Kesehatan. Sebuah Pengantar Proses Belajar Mengajar dalam Pendidikan. Yogyakarta: Graha Ilmu.

15. Nanlessy, Deissy Marcelien. et all. (2013). Hubungan antara Pengetahuan dan Perilaku Remaja Putri dalam Menjaga Kebersihan Alat Genetalia dengan Kejadian Keputihan di SMAN 2 Pineleng. e-journal Keperawatan (eKp) Volume 1. Nomer 1.

16. Notoatmodjo, Soekidjo. (2003). Pendidikan dan Perilaku Kesehatan. Jakarta: Rineka Cipta.

17. Nursalam. (2013). Metodologi Penelitian Ilmu Keperawatan. Jakarta: Salemba Medika.

18. Puspitaningrum, D. (2010). Praktik Perawatan Organ Genitalia Eksternal pada Anak Usia 10-11 tahun yang Mengalami Menarche Dini di Sekolah Dasar Kota Semarang. Diakses tanggal 6 Juni 2012. Pukul 18.28 WIB.

19. Ratna, D. P. (2010). Pentingnya Menjaga Organ Kewanitaan. Jakarta: Indeks p.1-2, 15-26, 83-86.

20. Rohmah, E. et all. (2013). Perilaku Remaja Putri dalam Merawat Organ Genitalia Eksterna selama Menstruasi pada Siswi Kelas XI di MAN Dolopo Kabupten Madiun.

21. Saadah, F. (2004). Tingkat Pengetahuan dan Persepsi tentang Haid/Menstruasi serta Perilaku Hygiene Menstruasi pada Pelajar Kelas II SLTP Negeri 1 Bogor tahun 2004.

22. Sari, I. P. et all. (2013). Pengaruh Pendidikan Kesehatan tentang Menstruasi terhadap Perubahan Perilaku Menstrual Hygiene Remaja
Putri untuk Pencegahan Infeksi Saluran Reproduksi (ISR).

23. Sarwono, S. (2006). Psikologi Remaja. Jakarta: Raja Grafindo Persada.

24. Scanlon, V.C. (2006). Buku Ajar Anatomi dan Fisiologi. Jakarta: EGC.

25. Siswono, A. (2001). Merawat Organ Reproduksi Perempuan. Jakarta: Sagung Setu.

26. Suliha, U. et all. (2001). Pendidikan Kesehatan dalam Keperawatan. Jakarta: EGC.

27. Syaifudin. (2009). Anatomi Tubuh Manusia untuk Mahasiswa Keperawatan. Jakarta: Salemba Medika.

28. Wardayati, T. (3 November 2013). Agar Organ Kewanitaan Selalu Terjaga Kebersihannya.

Cite This Article As: Muthoharoh, S., Widiyawati, R. Pengaruh Health Education Terhadap Perilaku Vulva Hygiene Saat Menstruasi Anak SD Umur 11 - 13 Tahun Di SDN Mojosari Kabupaten Mojokerto. Nurse and Health: Jurnal Keperawatan 2018; 7(1): 61-70. 